AWEJ for Translation \& Literary Studies, Volume2, Number 1, February 2018

DOI: http://dx.doi.org/10.24093/awejtls/vol2no1.14

Pp. 182-196

\title{
Translation Shifts in Spatial and Temporal Deixis: A Trend Towards a More Subjective Narrative Mood in Fiction Translation
}

\author{
Othman Ahmad Ali Abualadas \\ Department of English Language and Literature \\ The University of Jordan, Aqaba, Jordan
}

\begin{abstract}
This study examines the translational deictic shifts in three Arabic translations of the English novel Wuthering Heights and the effect of this shift in the spatio-temporal point of view and stylistic features of the original. The study finds shift in spatial and temporal deixis that manifests a strong tendency towards increasing the 'level of enunciation' of narrators' spatial and temporal location within the narrative. This shift brings the main narrator closer to the other characters in temporal, spatial, and mental space, hence increasing her involvement in events and empathy towards characters. At the same time, it distances the outside frame narrator, who has limited contact with characters, and increases his detachment and antipathy. In both cases more is revealed of narratorcharacter relationships and the narrator's evaluations, leading to a more subjective narrative mood. It is hoped that the study will be applicable to different translated literary works to compare the findings and gain more understanding on the norms of English-Arabic fiction translation.

Kew words: deixis, literary translation, narrative point of view, standardization, translation shifts

Cite as: Abualadas, O. A.A. (2018). Translation Shifts in Spatial and Temporal Deixis: A Trend Towards a More Subjective Narrative Mood in Fiction Translation. Arab World English Journal for Translation \& Literary Studies, 2 (1). DOI: http://dx.doi.org/10.24093/awejtls/vol2no1.14
\end{abstract}




\section{Research objectives}

This study explores different types of shift in the translation of spatial and temporal deictic expressions. The study will also explore the effect of these shifts in temporal and spatial settings of the original story. It will examine the change shifts can bring to the communicative features and narrative point of view of the original. It explores here how the trends of shifts can affect stylistic features that are implicit in the original narrative, such as narrator's degree of objectivity, involvement in or detachment from events narrated, antipathy to or empathy with characters etc.

\section{Corpus}

The corpus is the source text of Wuthering Heights by Emily Brontë (1847) and three Arabic translations of this novel. The novel has thirty-four chapters, but in order to provide in-depth examination and adequate contextualised explanation of the features being studied, full examination of the novel goes beyond the scope of this study. The study will therefore be focused on the first eight chapters of the novel (which contain 24,514 words). This is because the in-depth qualitative study can only be done on a focused corpus. The three Arabic translations are Ref'at Naseem (1972), Helmi Murad (1998) and Mamdouh Haqi (2011).

\section{Theoretical Background and Methodological Issues}

The framework for identifying deixis is based on Levinson's $(1983,2006)$ theory of deixis, which draws upon some previous influential accounts of deixis such as Fillmore (1975) and Lyons (1977). For the description of narrative point of view, the study adopts Simpson's (1993/2005, 2004) account, which is based on Uspensky's (1973) work on narrative point of view which was later refined by Fowler (1986/1996). The framework for analyzing deixis and point of view in the translation draws on certain translation studies in this specific area, most importantly, Munday (1997), Mason and Şerban (2003), Bosseaux (2007), Goethals (2007, 2009), and Richardson (1998).

Narrative point of view, as defined by Simpson (1993/2005, p. 4), is related to the psychological perspective through which the events of a story are narrated. It encompasses the narrative framework which the author employs to let the reader see and hear the events of a story or the basic viewing position which is adopted in narration.

Simpson (1993/2005, 2004), identifies four main categories of point of view: (i) spatial, (ii) temporal, (iii) psychological and (iv) ideological point of view (which falls outside the scope of this study). The spatial point of view is related to the viewing positions assumed by the narrator and concerns the camera angle adopted in the story (Simpson, 2005, p. 11). One language component that can contribute to the establishment of spatial point of view is spatial deixis, such as "here" "there" "this" "that", etc., which gives an index of location, distance and direction in the narrative description (Simpson, 2004, p. 29). Fowler (1996, pp. 62-65) resembles the spatial point of view in the narrative to the viewing position in visual art. He states that: "Just as painting is composed structurally so that the viewer seems to see some objects close up, some in the distance, some focussed, and some less clear" (Fowler, 1996, pp. 62-65).

The temporal point of view is generally related to the way relationships of time are expressed in the story. It can be related to any kind of manipulation of time sequence in the story, relating 
for examples to how certain events can be relayed as distant in time and others as immediate or imminent etc. (Simpson, 2004, p. 79), or as Fowler (1996, p. 127) puts it, it relates to "the impression which a reader gains of events moving rapidly or slowly, in a continuous chain of isolated segments". One of its linguistic markers can be time deixis, such as "now" "then" "this day" "that moment" etc. The two categories together are often referred to as "spatio-temporal point of view'.

The third category is 'psychological', or as Fowler (1996, p. 167) prefers to call it, 'perceptual' point of view. This category concerns the modes or ways in which the story events are mediated through the perception of the teller of the story, whether s/he is a narrator or a participating character. Fowler (1996, pp. 169-83) distinguishes here between two main types of narratorial viewpoints. The first one is an 'internal narrative', which is limited to the subjective viewpoint of a participating character's perception, manifesting her/his feelings, opinions or evaluation of events and other characters of the story. The second type is an 'external narrative', where events and characters are described from a position outside of any character's perception, allowing ostensibly for more objective reporting of events.

Researches such as Munday (1997) Mason and Şerban (2003), Goethals (2007, 2009) among others have indicated to some kind of translational deictic shifts which can bring about changes in the original narrative point of view. Munday (1997) studies shifts in point of view in an individual English translation (The trail of your blood in the snow) of the Spanish short story El rastro de tu sangre en la nieve, by García Márquez (1992). The narration mode of the story as Munday explains is a distanced third-person narrative, which is quite similar to a chronicle, with few personal markers of the omniscient narrator's world view, judgments or opinions. Time and place deictics are among the linguistic elements that have been examined and found to contribute to the shift in the 'spatio-temporal point of view of the original. Munday gives the following example.

1. ST: 'De no haber sido invierno, estarían ya en pleno día.'

TT: 'If it had not been winter, it would have been broad daylight by now.'

This sentence is told by the couple when they met. The use of distal deictic "ya" (already or then) indicates that the narrator is temporally-detached from the characters in the event. However, shifting this distal deictic into proximal "now" in the translation brings to this past episode a present prominence not existing in the original. It imposes a more immediate time frame on the story in the translation and brings the reader back closer to both characters and events narrated, affecting in turn the distancing point of view and the psychological perspective adopted in the original.

Jonasson (as cited in Bosseaux, 2007, p. 34 and Goethals, 2009, p. 773) studied the rendition of some deictic demonstratives in a number of narrative texts translated from French into Swedish. She finds that some of the used deictic expressions convey 'subjective point of view' in French and which may not be directly transposable into Swedish. She finds in most of these cases that the translator maybe "succeeded" in maintaining the subjective point of view adopted in the original by opting for other deictic elements in Swedish that can perform a similar function (Bosseaux, 
2007, p. 34). However, in several other cases, the translator opts for a non-deictic element, which contributes as she argues to "diminishing empathy" and making the "enunciation mode more objective" (Bosseaux, 2007, p. 34).

Mason and Şerban (2003), examine deictic translation shifts in a corpus of eleven literary translations from Romanian into English. Four main patterns of shift are found in the corpus: (i) shifting from proximal to distal, (ii) from a distal to proximal, (iii) omitting a proximal deictic via translation and (iv) adding a proximal or a distal via translation. The result that Mason and Şerban find is that there is a consistent pattern of distancing in translations; a tendency to use a distal more than proximal deictic via translation, projecting event and referents further away in time and space from the narrator and producing probably an 'alienating effect' (Fowler, 1996, p. 120).

Mason and Şerban (2003) argue that this narratorial detachment between the narrator and the referent or the events narrated here lead to a target text that elicits less 'involvement' on the part of the readers than the original text did in its context (see Hickey, 1998 and Boase-Beier, 2014). They argue that the use of proximal deictics ("now", "this" etc.) in a past-tense narrative, can signal the narrator's empathy or involvement in the event (Toolan, 1990, p. 178 and Klinger, 2014, pp. 64-66): it indicates that the narrator is re-living the events s/he narrates and hence inviting the reader to take part in her/his feelings and emotions at the time. But the distancing trend in the translation lead to a text with more objective rendering of the events on the part of the narrator and hence less involvement on the part of the reader with her/his world views.

Two studies carried out by Goethals $(2007,2009)$ do not confirm however the general distancing trend found by Mason and Şerban (2003). Goethals (2007), in a Dutch-Spanish corpus, finds that the proximal-distal alternations vary significantly between the different samples, manifesting no general trend toward distancing or approximating, while in his study (2009) of an individual Spanish translation of a Dutch novel, The Following Story, he finds these shifts occasional, not systematic, suggesting that such shifts are clearly not the result of a deliberate overall strategy of the translator. Goethals arguers that deictic shifts between source and target text should rather be seen as "the traces of the translator's interpretive search for the coordinates of the deictic center" and her/his attempts of resetting the context of the story (2009, p. 785). In other words, they should be looked at as traces the translator leaves of her/his translational interpretation in the translated text.

Another important conclusion about the translation of 'spatio-temporal point of view' can be found in Bosseaux (2007). In two French translations of the English novel The Waves (1931) by Virginia Woolf, using corpus processing tools, she studies the potential problems involved in the translation of linguistic elements that constitute the notion of point of view in order to see whether the translator's choices affect the original narrative viewpoints. Among these elements were person deixis "I", spatial "here" and temporal deixis "now". She finds 'a loss of deictic anchorage' in the translation of these elements in both translations. Compared to the original, both translations are found to keep fewer deictic elements which serve both to signal that the speakers are positioned within the situation they are talking about and to emphasize that the actions are taking place during the unfolding of the speakers' utterances, making the characters in the translation appear less involved than in the original. 
Before embarking on the analysis, the section below will briefly describe the source text which is to be analyzed, highlighting important stylistic features that could go affected by translation shift.

\section{Narrative Structure and Writing Style of Wuthering Heights}

The story of Wuthering Heights is presented in the form of eye-witness narrations by characters who have experienced the events they narrate, first by Lockwood, then followed by Nelly Dean (Goodridge, 1971, p. 16). Lockwood's narration represents the outer framework of the entire story, narrating the beginning and the end of the story and including some comments within. He acts as a recipient of Nelly's story and shapes the entire framework of the story. Nelly in turn tells the majority of the events and acts as a recipient of further narratives, those of other characters in the story such as Heathcliff, Catherine, Hindley etc. (Goodridge, 1971, p. 16).

The story is then told as "a series of flashbacks with overlapping time frames" (Gordon 1989, p. 139). It can be seen as a complex narrative structure which consists of stories-within-storieswithin-stories (McCarthy, 1984, p. 21). An example here is Isabella's comment on Heathcliff "Frightful thing! Put him in the cellar, papa. He's exactly like the son of the fortune-teller that stole my tame pheasant. Isn't he, Edgar?" (CH 6: 52). This is quoted in Isabella's warning to her father against Heathcliff, which is in Heathcliff's description of his journey to Linton house, which is in Nelly's story to Lockwood, which is in Lockwood's story to the reader. This multi-layered narrative technique has been seen as adventurous because it allows shifts in the point of view (from one character to another) and in time (from present to past and vice versa)(Oldfield, 1976, p. 53).

Emily Brontë's style varies depending on the narrator (Gordon, 1989, pp. 194-6). Lockwood, who functions as the outsider unused to rural life at Wuthering Heights and the moors, uses formal and mannered language, for instance, "a capital fellow" to refer to Heathcliff, "fascinating creature" to Cathy, and "the favoured possessor of the beneficent fairy" to Hareton (CH: 2). Unlike Lockwood, who is a stranger to the place, Nelly Dean lived through all events at Wuthering Heights and Thrushcross Grange and experienced the clash between the two families, and therefore is an actor in the drama and deeply engaged in the story events. She re-lives the past events as she narrates them and invites the reader to have an insider's view and take part in her emotions and feelings at the time. Goodridge (1971)describes her narrative:

Though copious and detailed, Nelly Dean's narrative has an extraordinary, sometimes breathless, energy as if she were describing events that she had witnessed an hour ago, every moment of which is vividly present to her. [...] she brings us very close to the action and is, in one way, deeply engaged in it: the intimate affairs of the Heights and the Grange have taken up her whole life. (pp. 18-19)

\section{Analysis and Results}

The data in this study indicate that 258 spatial deictics and 136 temporal deictics in corpus have undergone different types of shift after translation, suggesting a change in the spatial and temporal settings and the spatio-temporal point of view of the original. To explore the overall directions of shift in the corpus, the occurrences of the translational shifts in both types of deixis in the three translations are shown in the two tables below. 
AWEJ for Translation \& Literary Studies Volume, 2 Number 1, February 2018

Translation Shifts in Spatial and Temporal Deixis

Abualadas

Table 1. Spatial Deictic Shifts in the Three Translations

\begin{tabular}{|c|c|c|c|c|c|}
\hline & Type of shift & Haqi & Naseem & Murad & Total \\
\hline 1 & $\begin{array}{l}\text { shifting from a distal to proximal deictic (e.g. from } \\
\text { "that" to "this" or "there" to "here") }\end{array}$ & 12 & 13 & 34 & 59 \\
\hline 2 & $\begin{array}{l}\text { shifting from a proximal to distal deictic (e.g. from } \\
\text { "this" to "that") }\end{array}$ & 0 & 0 & 1 & 1 \\
\hline 3 & $\begin{array}{l}\text { shifting from definite article "the" to a distal } \\
\text { demonstrative such as "that" or "those" }\end{array}$ & 5 & 4 & 15 & 24 \\
\hline 4 & $\begin{array}{l}\text { shifting from the indefinite article to a distal } \\
\text { demonstrative }\end{array}$ & 2 & 0 & 2 & 4 \\
\hline 5 & $\begin{array}{l}\text { shifting from definite article "the" to a proximal } \\
\text { demonstrative such as" this" or " these" }\end{array}$ & 8 & 8 & 26 & 42 \\
\hline 6 & $\begin{array}{l}\text { shifting from the indefinite article to a proximal } \\
\text { demonstrative }\end{array}$ & 3 & 2 & 2 & 7 \\
\hline 7 & $\begin{array}{l}\text { shifting from possessive pronoun to a distal } \\
\text { demonstrative }\end{array}$ & 5 & 5 & 2 & 12 \\
\hline 8 & $\begin{array}{l}\text { shifting from possessive pronoun to a proximal } \\
\text { demonstrative }\end{array}$ & 13 & 11 & 17 & 41 \\
\hline 9 & adding the proximal adverb "here" & 12 & 9 & 3 & 24 \\
\hline 10 & adding the distal adverb "there" & 2 & 0 & 1 & 3 \\
\hline 11 & dropping the proximal place adverb "here" & 8 & 5 & 3 & 16 \\
\hline 12 & dropping the place adverb "there" & 1 & 1 & 2 & 4 \\
\hline 13 & $\begin{array}{l}\text { shifting from the distal adverb "there" to a prepositional } \\
\text { phrase (e.g. "in the Heights") }\end{array}$ & 2 & 2 & 3 & 7 \\
\hline 14 & $\begin{array}{l}\text { shifting from a proximal adverb "here" to prepositional } \\
\text { phrase }\end{array}$ & 4 & 2 & 2 & 8 \\
\hline 15 & $\begin{array}{l}\text { shifting from a distal demonstrative to the definite } \\
\text { article "the" }\end{array}$ & 0 & 2 & 1 & 3 \\
\hline 16 & $\begin{array}{l}\text { shifting from a proximal demonstrative to the definite } \\
\text { article "the" }\end{array}$ & 1 & 1 & 1 & 3 \\
\hline & Total & 78 & 65 & 115 & 258 \\
\hline
\end{tabular}

Arab World English Journal for Translation \& Literary Studies 
Table 2. Temporal Deictic Shifts in the Three Translations

\begin{tabular}{|c|c|c|c|c|c|}
\hline & Type of shift & Haq & $\begin{array}{l}\text { Nasee } \\
\text { m }\end{array}$ & $\begin{array}{l}\text { Mura } \\
\text { d }\end{array}$ & $\begin{array}{l}\text { Tota } \\
\text { l }\end{array}$ \\
\hline 1 & adding a proximal (e.g. "now" or "this night") & 15 & 10 & 13 & 38 \\
\hline 2 & adding a distal (e.g. "then" or "that day") & 8 & 7 & 7 & 22 \\
\hline 3 & omitting a proximal & 12 & 8 & 4 & 24 \\
\hline 4 & omitting a distal & 4 & 2 & 2 & 8 \\
\hline 5 & $\begin{array}{l}\text { shifting from a proximal to distal deictic (e.g. } \\
\text { from "now" to "then", or "see" to "saw") }\end{array}$ & 13 & 8 & 10 & 31 \\
\hline 6 & $\begin{array}{l}\text { shifting from a distal to proximal deictic (e.g. } \\
\text { from "that time" to "this time" or from "saw" } \\
\text { to "see") }\end{array}$ & 2 & 2 & 3 & 7 \\
\hline 7 & $\begin{array}{l}\text { shifting from the time adverb "now" or "then" } \\
\text { to prepositional phrase (e.g. "after } \mathrm{Mr} \\
\text { Earnshaw's death" }\end{array}$ & 3 & 1 & 2 & 6 \\
\hline & Total & 57 & 38 & 41 & 136 \\
\hline
\end{tabular}

The comparison of the data in these two tables reveals a number of significant trends. Firstly, there is a strong tendency towards adding rather than omitting a deictic via translating, suggesting a tendency towards adding temporal and spatial dimension to the target utterances and making target text more emphasized or marked from a deictic point of view than the original. Addition shifts are presented in the data by either (i) adding an extra time or place deictic via translating or (ii) translating a definite/indefinite article or possessive pronoun by a time or place deictic. Omission shifts, on the other hand, can be presented by either (i) dropping a time or place deictic or (ii) translating a time or place deictic by other means such as a definite/indefinite article or possessive pronoun. Table (3) and Figure (1) below compare the occurrences of these shifts in the three translations.

Table 3. Occurrences of Addition and Omission Shifts in the Three Translations.

\begin{tabular}{|l|l|l|l|l|l|}
\hline Type of shift & Haqi & Naseem & Murad & Total \\
\hline $\mathbf{1}$ & addition of a place deictic & 50 & 39 & 68 & 157 \\
\hline $\mathbf{2}$ & omission of a place deictic & 10 & 9 & 7 & 26 \\
\hline $\mathbf{3}$ & addition of a time deictic & 23 & 17 & 20 & 60 \\
\hline $\mathbf{4}$ & omission of a time deictic & 16 & 10 & 6 & 32 \\
\hline & Total & 99 & 75 & 101 & $\mathbf{2 7 5}$ \\
\hline
\end{tabular}

Arab World English Journal for Translation \& Literary Studies 


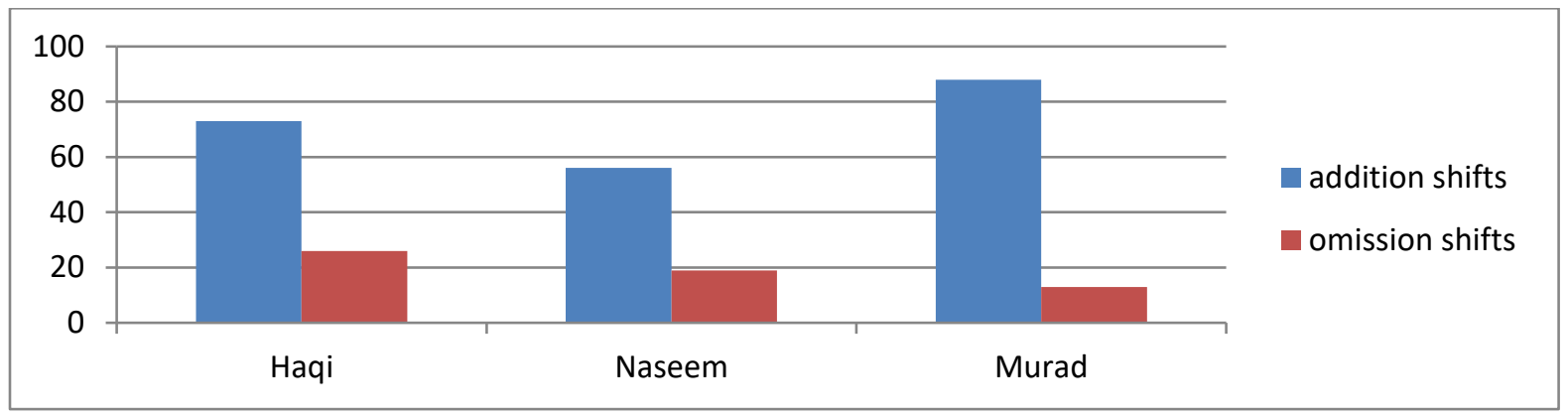

Figure 1. Comparison between Addition and Omission shifts

The data in Table 3 show that 217 deictics are added, whereas 58 are omitted via translating, indicating a significant trend towards adding a deictic (79\% of total addition and omission shifts). This trend of shift as the figure shows is manifested in each translation, but most significantly in Murad's translation. As can be evident from the data in the table, this trend is more marked in the translation of place deixis: $86 \%$ in place deixis, while $62 \%$ in time deixis. Regardless of these differences, the general trend here points to adding more deictic elements in translation and hence increasing the deictic anchorage of the target utterances by comparison with the source.

At the narrower level, the study found that out of the 217 deictics that have been added, 190 ( $88 \%$ of total added elements) are anchored to the narrators of the story, either Mrs. Dean or Mr. Lockwood, such as the addition of "that moment" in "Hareton had newly learned to walk, and started following me everywhere, and he was sitting near to me that moment", which is anchored to Mrs. Dean. While 27 of the added deictics (12\%) are anchored to characters in the story like Heathcliff or Catherine, such as "here" in "'What do you mean?' asked Heathcliff, 'and what are you doing here?", which is anchored to Heathcliff. What this may therefore suggest is a tendency to increase the level of enunciation of the narrator's position in place and time in relation to people and events in the narrative. This in other words suggests a target text that tends to signal the spatial and temporal location of the narrator more than in the original. This then seems to contradicts the results of Bosseaux (2007), which in two French translations of Virginia Woolf's novel The Waves finds a tendency towards losing deictic anchorage in the translation of spatial and temporal deictics because the translations keep less deictic elements than the original, and as result a tendency to put less emphasis on the narrators' position in the speech situation than the original. The shift in this study moves in the opposite direction.

The second trend the data manifest is a tendency towards using a proximal rather than distal deictic via translating. Approximating shift [-distance] is presented in the data by (a) shifting from a distal to proximal deictic, (b) adding a proximal via translation and (c) omitting a distal. Whereas distancing shift [+distance] occurs by means of (a) shifting from a proximal to distal deictic, (b) adding a distal via translation and (c) omitting a proximal. Table (4) below shows the occurrences of both approximating and distancing shifts in the three translations and Figure (2) compares the overall trends of shift. 
AWEJ for Translation \& Literary Studies Volume, 2 Number 1, February 2018

Table 4. Occurrences of Approximating and Distancing shifts

\begin{tabular}{|l|l|l|l|l|l|}
\hline & Type of shift & Haqi & Naseem & Murad & Total \\
\hline $\mathbf{1}$ & approximating shifts & 70 & 60 & 103 & 233 \\
\hline $\mathbf{2}$ & distancing shifts & 56 & 38 & 46 & 140 \\
\hline & Total & 126 & 98 & 149 & $\mathbf{3 7 3}$ \\
\hline
\end{tabular}

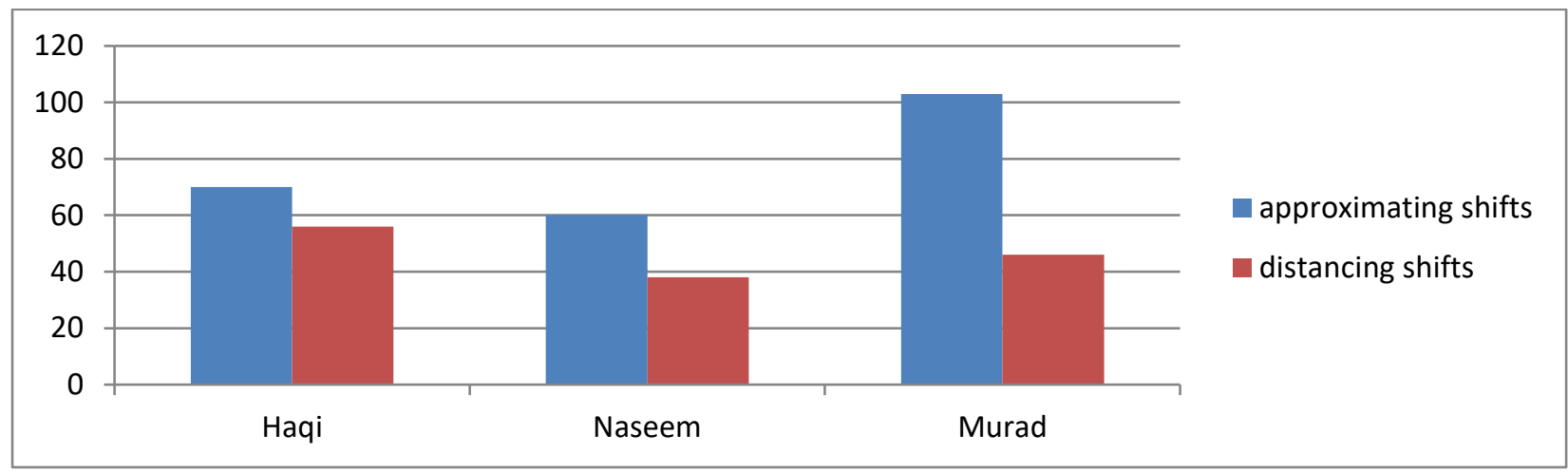

Figure 2. Comparison between Approximating and Distancing Shifts in the Spatio-temporal Point of View

The data in Table 4 indicate that there are 373 approximating and distancing shifts and among them 233 (62\% of total shifts) point towards approximating (-distance). As Figure (2) shows, this prevailing pattern is manifested in each individual translation, but it is slightly more significant in Murad and Naseem's translations than in Haqi's translation: it constitutes about 69\% and $61 \%$ of total shift in Murad and Naseem's translations respectively and $56 \%$ in Haqi's translation. What this trend can indicate is that there is an orientation in the three renditions towards bringing the referent or event closer, in both the psychological and physical space, to the speaker in the target utterances, suggesting an approximating shift in the spatio-temporal point of view of the original. To whom this trend is oriented (i.e. to the narrators or particular characters) and how it may affect the original will be discussed below.

As discussed before, the story of Wuthering Heights is eye-witness narrations by characters who have lived the events of the story, first by Mr. Lockwood, then followed by Mrs. Dean (see Goodridge, 1971; McCarthy, 1984 and Gordon, 1989). Mr. Lockwood shapes the outer framework of the entire story and receives Mrs. Dean's story, while Mrs. Dean narrates most of the events and acts as a recipient of further 'tertiary narratives', of other main characters in the story such as Heathcliff, Catherine, Edgar etc. (Goodridge, 1971, p. 16). With regard to approximating and distancing shifts in the three translations, the study finds that both are oriented towards the two 
narrators of the story, Mr. Lockwood and Mrs. Dean, rather than any other characters in the story. Among the 373 approximating and distancing shifts, 343 instances (92\% of total shifts) involve time and place deictics that are anchored to the narrators and therefore shift the viewing positions assumed by them in the narrative. But with regard to the approximating shifts, which are dominant in the translations, the study found that they mostly change the position of Mrs. Dean, the main narrator of the story. $86 \%$ of the deictics that have undergone approximating shift are found to be anchored to her.

What can be argued here is that the approximating trend found in the data may affect the psychological positioning of the main narrator towards the characters and events within the narrative on one hand, and the target reader towards the main narrator and the narrated events on the other. As explained before, depictions of spatial-temporal points of view may contribute to the construction of the narrator's 'psychological point of view' (Uspensky, 1973) as their emotions and thoughts can affect their perception, and in turn their depictions, of their spatial and temporal viewpoints in the story (Fowler, 1996, see also Morini 2014, pp. 131-32). The study argues here that approximating the viewpoints can change the modes in which the story events are mediated through the perception of the narrator (Simpson 2005: 10) and affect hence the relationships between the narrator and character and the psychological perspective adopted in the original.

Take for example "this" which originally has been "that" in Mrs. Dean's comment on Hindley's wife before her death "Poor soul! Till within a week of her death this gay heart never failed her" or the addition of "this night" in her description to Mr. Lockwood of how was Christmas Eve to her "... and then I remembered how old Earnshaw used to come in this night when all was tidied, and call me a cant lass, and slip a shilling into my hand as a Christmas-box". The use of the proximal gives the past event here present prominence and brings both the events and characters emotionally closer to Mrs. Dean and also to the reader by inviting her/him to take part in Mrs. Dean's emotions and feelings at the time. The past event or past state has become here "more vivid and more 'real' by actualising them" (Richardson, 1998, p. 133). The spatial and temporal proximity can therefore suggest more subjectivity on the part of the narrator in the narration (Toolan, 1990, pp. 178-81), and hence leads to a narrative that elicits more involvement on the part of the narrator in the story and on the part of readers with the narrator's feelings by comparison with the original (see Klinger, 2015, pp. 64-66).

Although the distancing shifts as the data show are less frequent compared to approximating shifts, the study finds that cases of distancing spatial viewpoints in the three translations can be in some way systematic and may reflect a strategy of the translator. Among the 63 distanced spatial viewpoints, 44 instances (70\% of total distanced viewpoints) involve shift from an unmarked form for proximity (such as a definite/indefinite article or possessive pronoun to the marked distal "that" and "those". This can reflect emotional or psychological distance (Levinson, 1983, p. 81, Fowler, 2009, pp. 119-20) between the narrator and the characters in the event narrated. The study finds that this shift has happened mostly in utterances which may express on the part of the narrator, most often Mr. Lockwood, antipathy to a particular character or event. Take for example the translation of "the dignity" as "that dignity" in Mr. Lockwood's comment when Hareton announces himself very gruffly "laughing internally at the dignity with which he announced himself", or the translation of "his habitual moroseness" as "that habitual moroseness" in his 
comment on Mr. Heathcliff after having been bitten by dogs and guided into a room to rest "Mr. Heathcliff followed, his accidental merriment expiring quickly in his habitual moroseness". The distancing here suggests Mr. Lockwood's antipathy to Hareton's response and Mr. Heathcliff's character, indicating implicit narratorial detachment (Toolan, 1990, pp. 178-81).

The study argues that the translational trends here can reflect a strategy of the translator and affect the original narrative point of view in some way. As discussed before, Mrs. Dean's narrative is a re-living account of the past events because she lived through most events at Wuthering Heights and Thrushcross Grange and seen the clash between the two families: Earnshaws and Lintons, and therefore she is deeply engaged in the events she narrates (Gordon 1989, pp. 194-6). Since approximating shifts make her closer to characters and more engaged in the story, it can be argued that the approximating trend here may reflect an attempt on the part of the translator to emphasize her personal feelings and emotions and her subjective point of view and hence to maintain this feature of the narrative style in the target text.

But for Mr. Lockwood, who starts narrating the story after his disastrous night at Wuthering Heights and having met its mysterious residents and been attacked by their dogs, he is an outsider to the Heights and what he sees or hears there is sometimes "beyond [his] comprehension" $(\mathrm{CH}$ 3). Distancing shifts, which here centre on him more than Mrs. Dean, may reflect the translator's orientation to reflect the narrator's negative attitudes towards characters and events. But again, because he is stranger to the whole place and the story actions, his narration is often characterized as unbiased and more objective than Mrs. Dean's and his language is not then as dramatized as Mrs. Dean's (Gordon, 1989, pp. 194-6, Oldfield, 1976, pp. 51-52). Distancing, and the negative evaluations suggested here, may then make his narration more subjective and dramatized than the original.

Approximating and distancing shifts may then suggest a degree of involvement on the part of the translator with the text during translation process and reflect her/his interpretive position. One for example might say that the shifts here may reflect the translator's association and involvement with the two narrators' personal feelings and emotions in the story, or her/his personal conception of the realities she/he is expressing. Even this might normally suggest a degree of 'translation subjectivism', fiction translation may require a reconstruction of realities depicted in the original, which can be achieved only after the translator apprehends realities like place and time settings, narrator-character relationship, ideological intentions etc. (Levý 2011, pp. 31-38, see also Eco, $2001 / 2008$,) and translators' choices are often "constrained by what they understand was said" in the original story (Chesterman, 2004, p. 44 emphasis in the original).

The third trend the study found is that in comparison to spatial deictics there is a tendency to use a time distal rather than a proximal via translation. Despite that the overall effect of the translational shifts is an approximating trend in the spatio-temporal point of view, the shifts in temporal deixis, unlike spatial deixis, point to a distancing trend rather than approximating. Figure (3) and (4) below compare between the general trends of the shift in both types of deixis. 


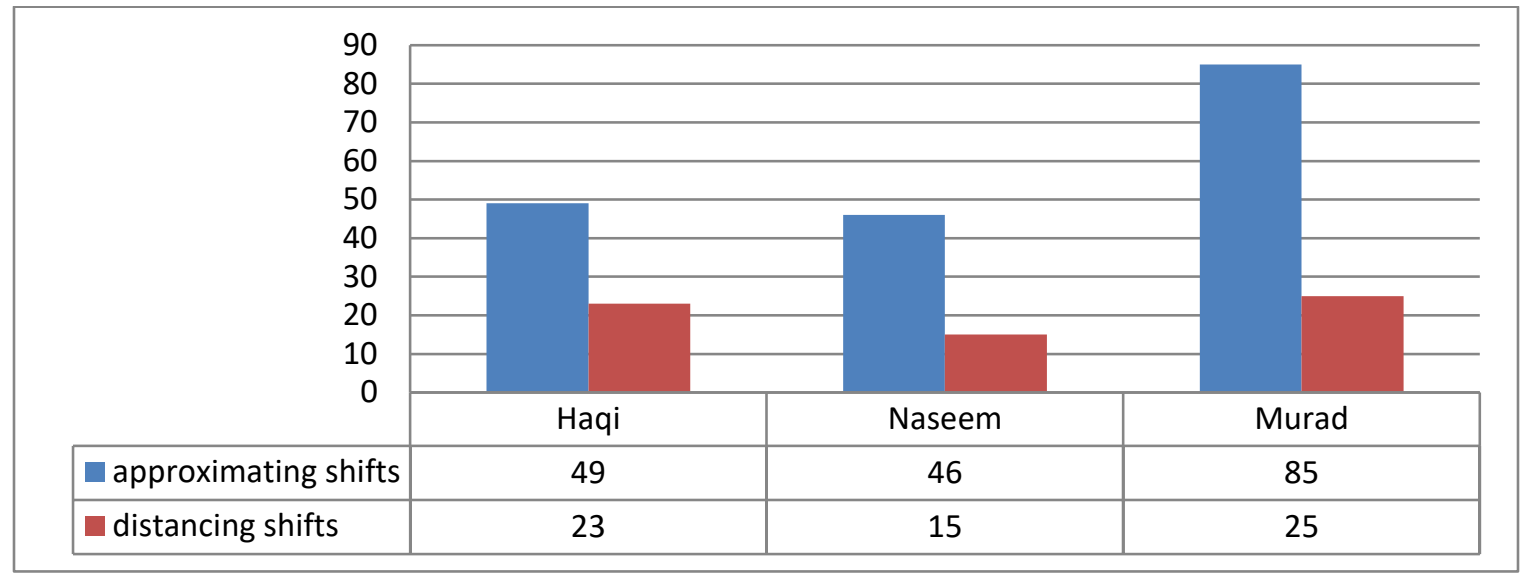

Figure 3. Approximating and Distancing Shifts in Spatial Deictics

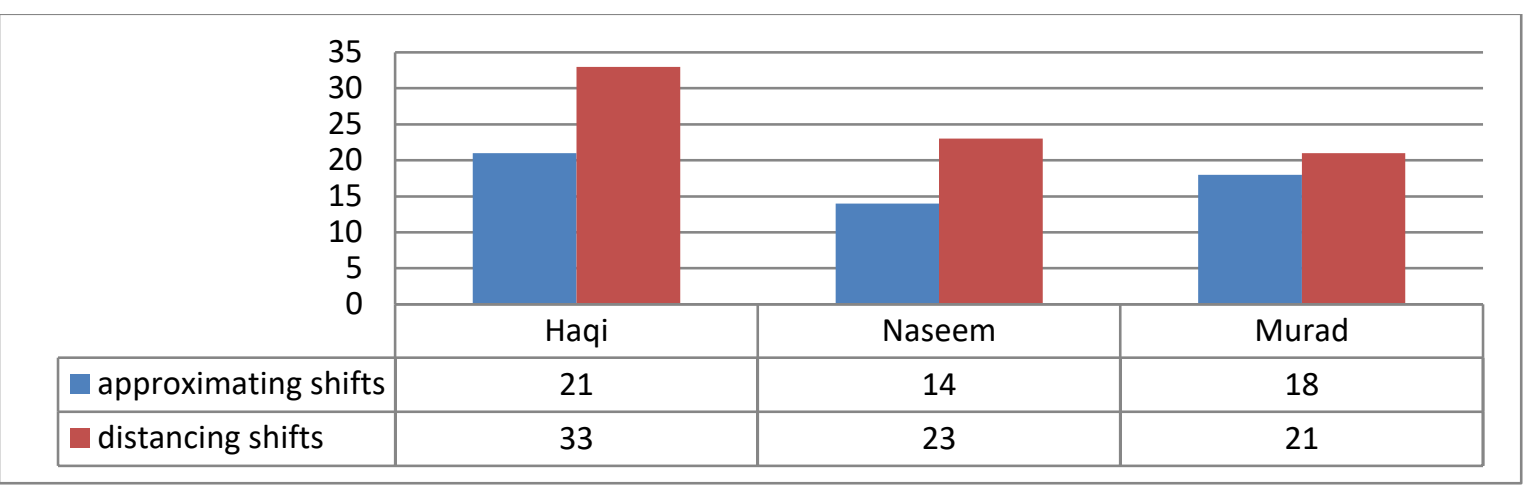

Figure 4. Approximating and Distancing Shifts in Temporal Deictics

The data in Figure 4 indicate that the shift in temporal deictics, which constitutes $33 \%$ of total shifts compared to spatial deictics $(62 \%)$, points to a tendency towards using a distal deictic, indicating a distancing trend in the temporal point of view. This distancing trend as the data indicate can be manifested in each translation, and similar to the previous trend the study found it to be centred on the two narrators of the story: Mr. Lockwood and Mrs. Dean. This temporal distancing may therefore have the effect of pushing the two narrators further in time from the referent and the event narrated. It makes them more temporally-distanced and hence less emotionally-involved in the events narrated. Take for example "tomorrow" which is rendered as "the following day" in Mr. Lockwood's utterance "and before I went home, I was encouraged so far as to volunteer another visit tomorrow", which makes him more detached in time from the event at the coding time and less involved in the event narrated. Distancing here may also have the effect of reducing the narrators' subjective point of view and hence increasing objectivity of the narration in the target utterance (see Toolan, 1990, p. 188 and Fowler 1996/2009, p. 121). Take for instance Mrs. Dean's utterance after sending Hindley to a boarding school to get rid of his troubles at home "I hoped heartily we should have peace now", where "now", which in this pasttense narration indicates that she is still emotionally-involved, is translated as "after that". The 
translation pushes Mrs. Dean away from the event and makes her reporting of the event more objective than in the original utterance.

The study, however, argues that this distancing trend in the translation of temporal deictics may be considered an example of 'normalization' or 'standardization' in translation (Toury 1995/2012, see Munday 2008, pp. 31-32). Since it is normal in conventional narrative to use a deictic form (i.e. distal vs. proximal) that reconciles with the narrative tense (i.e. past vs. present) (Toolan 1990: 178), the trend here can be argued to reflect an attempt on the part of the translator to normalize the expression in the target language through opting for a deictic form that is consistent with the past tense used in the narration. The study found that most cases of adding a time distal, dropping a time proximal or shifting from a time proximal to distal have occurred where past tense is used in the narrative (take for example the two examples above). Accordingly, what can be suggested here is that in addition to the approximating pattern which is in operation in the three translations, another pattern of shift seems to go in the opposite direction in an attempt to keep the expression unmarked in the target language (see Øverås 1998).

What can be noticed then is that the shifts in spatial and temporal go in different directions. While spatial deictic shifts point to approximating and greater narratorial subjectivity and involvement, temporal deictic shifts point on the other hand to distancing and greater objectivity and detachment. The findings here seem to only partially confirm the results of Mason and Şerban's study (2003), which finds an overall tendency towards distancing both the spatial and temporal viewpoints of the original, with the narrator less involved and more objective in the narration.

\section{Conclusion}

Translation shifts in spatial and temporal deixis have manifested a strong tendency towards increasing the 'level of enunciation' (Jonasson, 2001, Bosseaux, 2007) of narrators' spatial and temporal location within the narrative, with the main narrator who is 'deeply engaged' in the story (Goodridge, 1971, Gordon, 1989) more 'approximated' (Munday, 1997), and with the 'outside frame narrator' who is new to the story events and has had little contact with characters (Gordon, 1989) more 'distanced' (Mason and Şerban, 2003). This has pointed to increasing 'narratorial involvement' and 'empathy towards characters' (Fowler, 1996) on the part of the main narrator, but 'narratorial detachment' and 'antipathy' on the part of the outside frame narrator. Both approximating and distancing in viewing positions have suggested, within the context of the story, a shift towards a more 'subjective' (Fowler, 1996) reporting of events in the translation. The shift may however be attributable to the translator's representation of her/his 'conception' or 'concretisation' of the original story (Levý, 2011) and sometimes her/his attempts to 'standardize' its language and style (Toury, 2012).

\section{About the Author}

Dr. Othman Abualadas is assistant professor in Linguistics and Translation Studies in The University of Jordan in Aqaba and the head of Department of English Language and Literature in the university. Dr. Othman Abualadas teaches linguistics and translation courses for undergraduate and graduate students. 
AWEJ for Translation \& Literary Studies Volume, 2 Number 1, February 2018

Translation Shifts in Spatial and Temporal Deixis

Abualadas

\section{References}

Boase-Beier, J. (2014). Stylistics and Translation. In: M. Burke, ed. The Routledge Handbook of Stylistics. London and New York: Routledge, pp.393-407.

Bosseaux, C. (2007). How Does it Feel? Point of View in Translation: The Case of Virginia Woolf into French. Amsterdam: Rodopi.

Brontë, E. (1967). Wuthering Heights. London: Zodiac press.

Chesterman, A. (2004). Beyond the Particular. In: Mauranen, A. and P. Kujamäki, eds. Translation Universals: Do They Exist? Amsterdam and Philadelphia: John Benjamins, pp.34-49.

Eco, U. (2001/2008). Experiences in Translation (translated by Alastair McEwen). Toronto: University of Toronto Press.

Fillmore, C. (1975). Santa Cruz Lectures on Deixis. Bloomington: Indiana University Linguistic Club. (Reprinted as Fillmore, C. 1997 Lectures on Deixis. Stanford. CA: CSLI Publications).

Fowler, R. (1981). Literature as Social Discourse: the Practice of Linguistic Criticism. London: Batsford Academic and Educational.

Fowler, R. (1986/1996). Linguistic Criticism, $2^{\text {nd }}$ ed. Oxford: Oxford University Press.

Goethals, P. (2007). Corpus-driven Hypothesis Generation in Translation Studies, Contrastive Linguistics and Text Linguistics: A Case Study of Demonstratives in Spanish and Dutch Parallel Texts. Belgian Journal of Linguistics, (21): 87-104.

Goethals, P. (2009). Deictic Center Shifts in Literary Translation: The Spanish Translation of Nooteboom's Het Volgende Verhaal. Meta, 54 (4): 770-794.

Gordon, F. (1989). A Preface to the Brontë. London and New York: Longman.

Haqi, M. (2011). Murtaf'at wuthering. Amman-Jordan: Jordanian Ministry of Education.

Hickey, L. ed., (1998). The Pragmatics of Translation. Clevedon: Multilingual Matters.

Klinger, S. (2014). Translation and Hybridity: Constructing World-View. London and New York: Routledge.

Levinson, S. (2000). Presumptive Meanings: The Theory of Generalized Conversational Implicature. Cambridge: The MIT Press.

Levinson, S. (2006). Deixis. In: Horn, R. and G. Ward, eds. The Handbook of Pragmatics. Oxford: Blackwell Publishing, pp.97-121.

Levý, J. (2011). The Art of Translation, translated by Patrick Corness. Amsterdam and Philadelphia: John Benjamins.

Lyons, J. (1977). Deixis, Space and Time. In: Semantics. Cambridge: Cambridge University Press.

Mason, I. \& Şerban, A. (2003). Deixis as an Interactive Feature in Literary Translations from Romanian into English. Target, 15 (2): 269-294.

Morini, M. (2013). The Pragmatic Translator: an Integral Theory of Translation. London: Bloomsbury.

Morini, M, (2014). Translation, Stylistics and To the Lighthouse: A Deictic Shift Theory Analysis. Target, 26 (1): 128-145.

Munday, J. (1997). Linguistic Criticism as an Aid to the Analysis of Literary Translation. In: Klaudy, K., Kohn, J. and M. Snell-Hornby, eds. Transferre Necesse Est, Proceedings of the Second International Conference on Current Trends in the Study of Translation and Interpreting. Budapest: Scholastica.

Munday, J. (2008). Style and Ideology in Translation. New York and London: Routledge.

Arab World English Journal for Translation \& Literary Studies 
Murad, H. (1998). Murtaf'at wuthering. Damascus and Beirut: Dar Al-Bashir.

Naseem, R. (1972). Murtaf'at wuthering. Beirut-Lebanon: Dar Al-Qalam.

Oldfield, J. (1976). Jane Eyre and Wuthering Heights: A study Guide. London: Heinemann Educational Books Ltd.

Øverås, L. (1998). In Search of the Third Code: An Investigation of Norms in Literary Translation. Meta, 43 (4): 557-570.

Richardson, B. (1998). Deictic Features and the Translator. In: L. Hickey, ed. The Pragmatics of Translation. Clevedon: Multilingual Matters, pp.124-142.

Saldanha, G. (2011). Translator's Style. The Translator, 17 (1): 25-50.

Simpson, P. (1993/2005). Language, Ideology and Point of View. London and New York: Routledge.

Simpson, P. (2004). Stylistics: A Resource Book for Students. London and New York: Routledge. Telgen, D. (1997). Novels for Students, Vol. 2. Detroit: Gale.

Toolan, M. (1990). The Stylistics of Fiction: A Literary Linguistic Approach. London and New York: Routledge.

Toury, G. (1995/2012). Descriptive Translation Studies-and beyond. Amsterdam and Philadelphia: John Benjamins.

Uspensky, B. (1973) A Poetics of Composition, trans. V. Zavarin and S. Wittig. Berkeley: University of California Press. 